\title{
"A HASTILY CORRECTED SLIP": LITERARY AND DEMOCRATIC COLLECTIVITY IN A NEW WHITMANIAN ARTIFACT \\ NATHAN SCHMIDT
}

In Bloomington, IndianA, in the vault of the Lilly Library, there is a document written in Walt Whitman's hand that has never before received sustained critical attention. The document, which might be best described as a simple collage, was acquired by the Lilly Library at Indiana University in $2011 .{ }^{1}$ It is a piece of newsprint pasted onto a thicker sheet of heavy wrapping paper, accompanied by a somewhat ramshackle frame. The text of the newsprint is from an interview that Whitman gave to a reporter for the St. Louis Post-Dispatch on October 17, 1879. Whitman clipped the original interview from the Post-Dispatch, pasted it to the wrapping paper, and cut off the top of the original clipping to replace it with a new, handwritten introduction. He made several manuscript changes to the interview in the marginal space he created by pasting the clipping onto the heavier paper, producing an alternate version of the text that has never been published in full. ${ }^{2}$ A large square of paper at the top, webbed with Whitman's thin, flowing script, leads to a skinny strip of newsprint glued messily to its dark brown sheet. Near the top of the backing paper, Whitman has written "read Proof carefully by Copy," in the sort of blue pencil that an editor would have used to dash off instructions before sending an article to the press. Whitman, who always had a high estimation of himself as a printer, frequently used a pencil like this on his own manuscripts. ${ }^{3}$ Overall, viewing the scribbled notes on the sloppily pasted and acid-aged newsprint gives the impression of something both monumental and gossamer, unwieldy and delicate-in other words, the piece taken simply as an object is already strikingly Whitmanian. This cobbled-together document - which ultimately proved unprintable - is a reminder of the less-than-subtle pun in the title of Leaves of Grass: "leaves" 
(pages) of unprintable "grass."

Whitman himself did not provide the frame. That was added in 1900 by Robert Underwood Johnson, the reporter to whom Whitman sent the collage. Johnson, in his autobiography Remembered Yesterdays (1923), recalled the moment he briefly crossed paths with Walt Whitman: "In 1879 I saw a report of an interview with [Walt Whitman] in St. Louis in which he spoke vaguely of the neglect that had been shown to certain younger writers, and I wrote to him to inquire who these were, as at that time the editors of the Century were professionally engaged in discovering genius." Johnson worked on staff for Josiah Holland at the New York periodical Scribner's Monthly, later renamed the Century - a periodical he would one day spearhead, along with becoming a diplomat and a campaigner for copyright. Whitman received Johnson's letter when he was in St. Louis and responded to it on October 29, 1879. "Dear Sir," Whitman wrote, "Your note has just reached me here, where I am temporarily stopping-I could not well tell you the names of the 'young men referred to' because I spoke mainly of a class, or rather of a leaven \& spirit." ${ }^{\prime 5} \mathrm{He}$ goes on to bemoan how a certain interview that he gave to a St. Louis reporter a few weeks earlier, on October 17, was "extracted from in so dislocated \& awry a manner" that it was necessary that he "enclose a hastily corrected slip," hoping Johnson might "know some N Y paper or literary publication in whose line it might come."

In 1879, Johnson's star was rising in the New York periodical market, and he would become the magazine's associate editor just two years later, in 1881, after Holland's death. What could be more fortuitous for an ambitious New York reporter than the chance to correct the record, to publish an updated account of an interview given by one of America's signature literary voices, corrected in the author's own hand? Yet instead of making any attempt to publish the piece, Johnson quietly kept it to himself for twenty-one years until, in 1900, he had it framed and matted and hung on the wall. Johnson may have been reasonably refusing to be Whitman's pawn in a gambit for free publicity-but then why did he save the interview and display it where visitors would be able to see it?

This document affords an opportunity to explore the complicated interaction of Whitman's personal notoriety and his ostensible democratic egalitarianism, along with providing a useful snapshot of his relationship to the press in the late 1870's. If Leaves of Grass really was "no book," if who touched it touched not a poem but a man, ${ }^{6}$ then Whitman's entire poetic career can be described as a project of self-editing, the dual articulation of poetry and persona. As I will show here, this document, so far barely known to Whitman scholars, offers a 

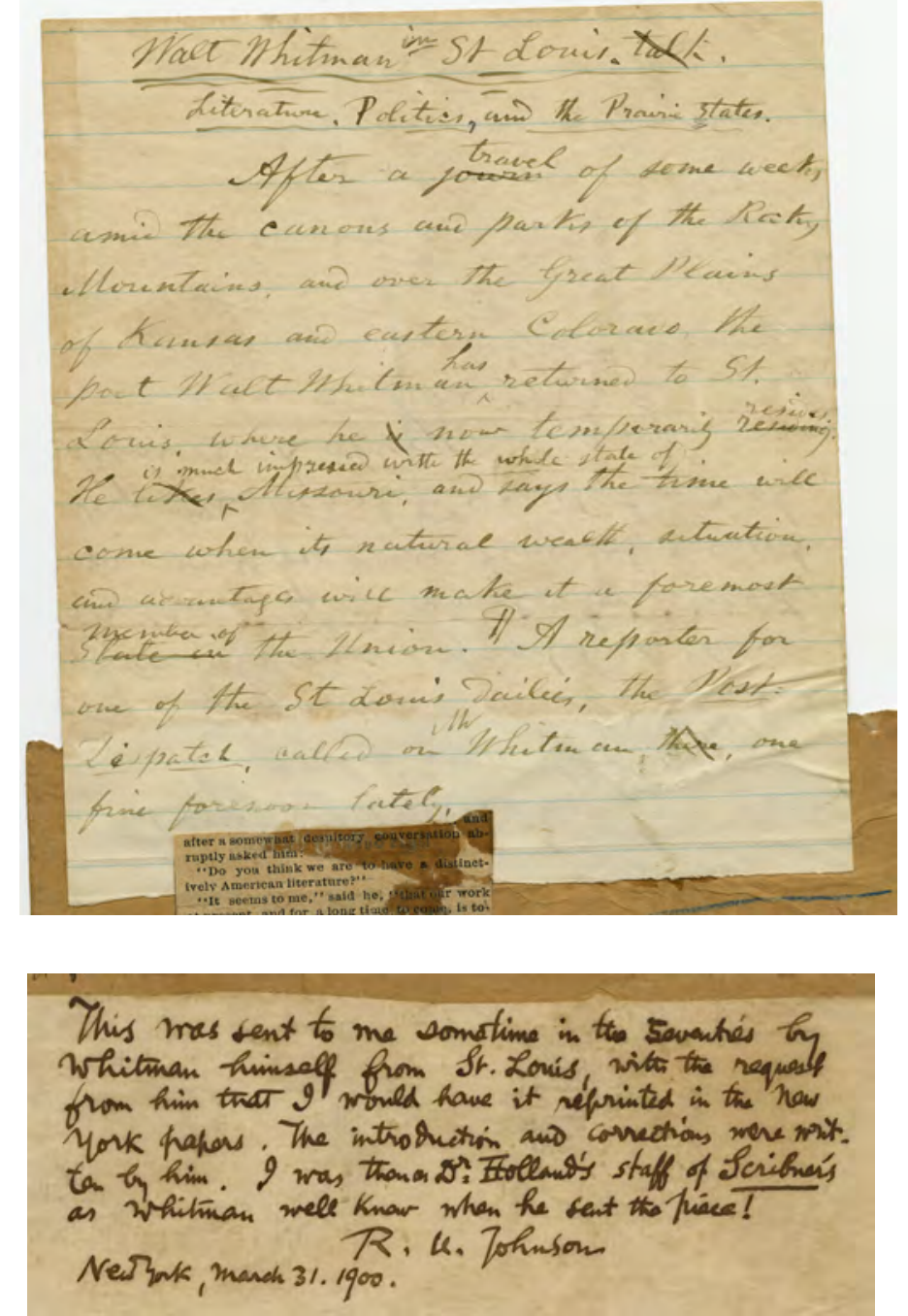

Right: Recto of newspaper interview from the St. Louis Post-Dispatch with corrections, comments, and augmentations in Walt Whitman's hand. From the Lilly Library at Indiana University in Bloomington, Indiana. Above: Details from the recto, including Whitman's new introduction and a postscript by Robert Underwood Johnson.

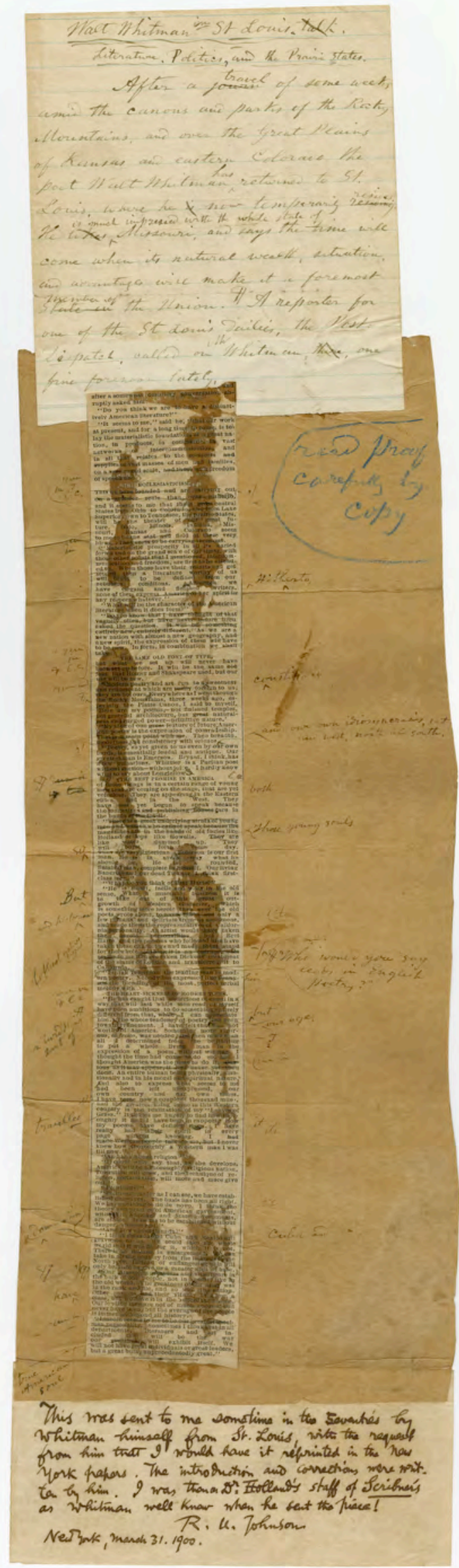


glimpse into the ways Whitman managed that persona beyond the poetry, in the broader field of public discourse. Whitman's revisions can be read as attempts to restore what he actually said to the journalist and what was subsequently misrepresented in print, but even if it is the case that his words really were printed in a "dislocated \& awry" manner, I propose that there is more to this story. Whitman treated this interview as an occasion to balance the contradictions between public utterance and private belief, between writing for and about oneself and writing for a growing audience of both fans and detractors.

\section{$\star$}

While his notoriety may prompt a reader to focus primarily on the parts of this document that are in Whitman's hand, his is not the sole pen of authorship. In 1900, Robert Underwood Johnson wrote a note to accompany to the piece, which he attached to the bottom of the clipping Whitman sent him. Written in his bold, thick handwriting, it further complicates the bizarre collage:

This was sent to me sometime in the Seventies by Whitman himself from St. Louis, with the request from him that I would have it reprinted in the New York papers. The introduction and corrections were written by him. I was then on Dr. Holland's staff of Scribner's as Whitman well knew when he sent the piece!

R. U. Johnson.

New York, March 31, 1900

The final exclamation mark indicates what may be bemusement and may be indignation on Johnson's part. Whitman unflatteringly referenced his boss, Josiah G. Holland, who, while rarely read today, was a well-known figure in the literary establishment at the time, working prolifically as a poet, historian, novelist, and advice columnist. ${ }^{7}$ The reference would have caught Johnson's attention when he first read the article; hence this request that Whitman name some of his imagined neglected writers. In addition, he certainly would have taken note that, even in the revised version Whitman sent him as a response, he had done nothing to tone the insult down. Crossing out several words in the original article, Whitman edited the passage to read as follows: "They have not yet begun to speak because the magazines and publishing houses are in the hands of the fossils. There is a great underlying strata of young men and women who eannot speak beeause the magazines are in the hands of old fogies like 
Holland or fops like Howells."

It is possible that all Whitman would have needed to do was drag the pencil an inch further, crossing out the words "old fogies like Holland," to make the interview publishable. But Whitman kept the jab at Holland, crossed out his reference to the "great underlying strata" instead, and then Johnson framed the piece and hung it on the wall. Watching the story unfold in retrospect, one is inclined to ask: has Johnson called the bard's bluff? Is Whitman's entire project in his reply to Johnson simply to obscure his inability to name a single one of the "great underlying strata" to whom he wills the future of American literature? Why else would he have sent a text that Johnson simply couldn't have published? What is the canny Walt Whitman up to here? No wonder Johnson's befuddlement is such that, twenty-three years after he first suggests it in his note about the piece in 1900, he still insists in his memoir that Whitman must have known that Holland, the "old fogey," was Johnson's chief at Scribner's. ${ }^{8}$

Some attention to the fact of the matter-Whitman's corrections to the "dislocated \& awry" parts of the interview-will shed some light on these questions and prove to be both illuminating and confounding by turns. The majority of Whitman's changes to the original text of the interview, after a florid new introduction pasted on at the top, are deletions, although there are a handful of insertions scribbled in the margins. There are also several words in the original text that were placed in block capitals in the center of the column-Whitman the printer seems to find this off-putting, and he marks for them to be taken back up into the rest of the paragraph at each point they occur.

Yet this piece and the narrative of its creation have more to offer the field of Whitman scholarship than simple archival curiosity, as valuable as such curiosity may be in and of itself. By carefully considering a few specific examples of major changes that Whitman made to the original text of the interview, I will show that Whitman's revised interview affords the reader an opportunity to see Whitman's first-hand working out of a key problematic in his work: that of the relationship between the individual artist and the democratic mass he imagined to be necessary for the development of a budding republic of American literati. How does Whitman negotiate his calculating cultivation of his individual artistic image when the backbone of his poetics is precisely the attempt to articulate the voice of the multitudes? What is the relationship between the attempt to speak in the name of a certain "leaven \& spirit," in manifold tongues, and the complications that stem from working in a literary marketplace built on the promotion of individual genius? 
Editing himself in public was hardly a novelty for Whitman in 1879. Of course, his Leaves of Grass had already seen multiple editions that were significantly different from one another, but 1879 was a substantial year for Whitman to ventriloquize himself in other ways. In September, while he was in Denver, Whitman hand-wrote his own "interview," including introductory remarks by a fictional reporter, and sent it to the editor of the Denver Daily Tribune, ${ }^{9}$ and in August he sent a description of himself for John Burroughs to include, intentionally without attribution, in his essay on "Nature and the Poets,"10 in which he celebrates himself as a democratic poet and offers a brief characterization of his relationship to natural history. The particular collage of newsprint and manuscript Whitman made in St. Louis uniquely allows the reader to see this process of ventriloquism worked out firsthand, as a test case for the way Whitman handled his individual notoriety in relation to his experimental project of a democratic poetics that runs through so much of his writing. While the language of poetry gave him the freedom to contradict himself, to speak in the first person and simultaneously claim to contain multitudes, Walt Whitman the public intellectual finds himself unable to speak truly for Walt Whitman the poet without revision. He does indeed contain multitudes, but not in exactly the same sense he spoke of in his famous line from "Song of Myself." 11 In this interview, Whitman's problem is precisely that he contains, not the chaotic manifold of persons listed out in "Crossing Brooklyn Ferry," but a multitude of potentially irreconcilable Walt Whitmans - the "Good Gray" poet of literary celebrity, the printer, the public speaker, the prose essayist and literary prognosticator, the editor, the amateur political philosopher. It is therefore hardly surprising that he finds himself at this moment grappling with the question of the relationship between the poetic individual and his mass audience.

The verso of the collage is particularly interesting for our understanding of how Whitman grapples with the commodification of his public persona. Johnson's addition to the bottom of the piece bleeds through the paper on which he wrote it, and the back of the heavy paper to which Whitman pasted his edits has some notes from the framer: "Mount on green board"; "show 1 1/2 top and sides"; "2 bottom"; " $3 / 4$ green frame." These brief instructions, probably from Johnson, could indicate the meticulous care Johnson took in preserving his piece of Whitman memorabilia, suggesting the staying power of Whitman fandom in the generation immediately following his death. As David Haven Blake notes in Walt Whitman and the Culture of American Celebrity, "Prepared to bargain himself in the cultural marketplace, Whitman reflected the Gilded 


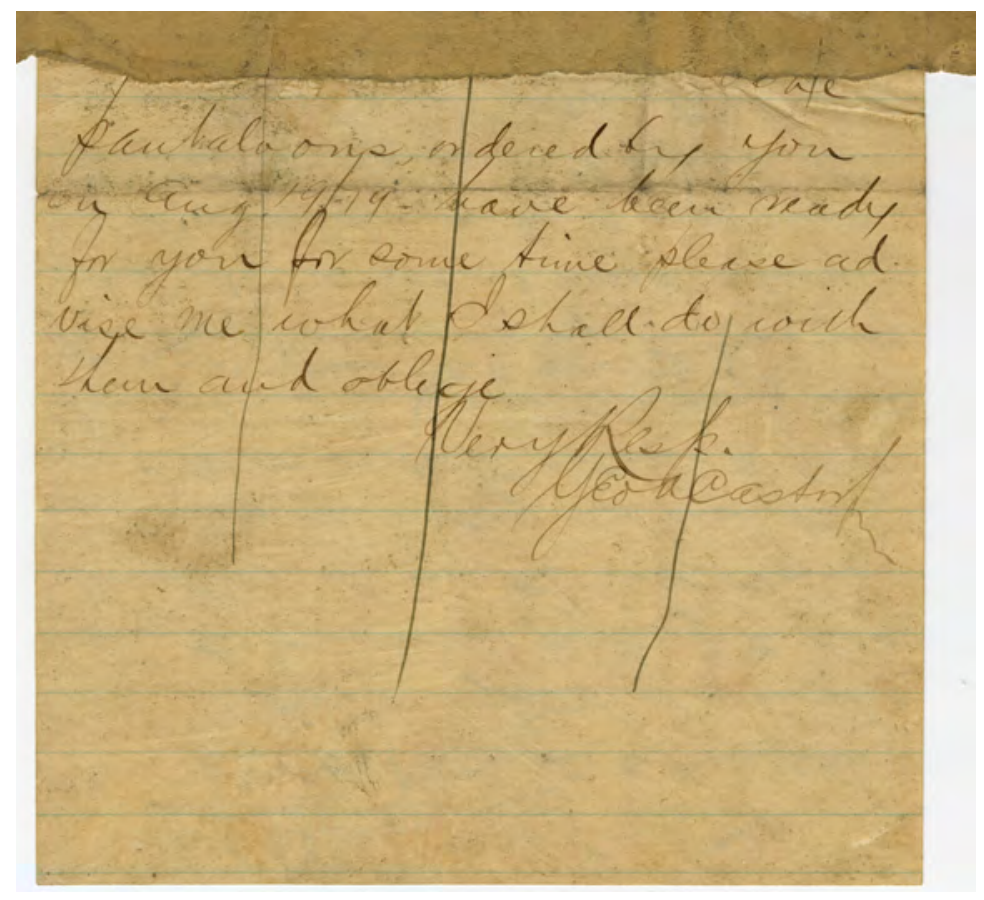

Right: Verso of newspaper interview from the St. Louis Post-Dispatch with corrections, comments, and augmentations in Walt Whitman's hand. From the Lilly Library at Indiana University in Bloomington, Indiana. Above: Detail from the verso, a letter from Whitman's tailor, George A. Castor. 
Age's enthusiasm for the commodification of personality." 12 The very fact that Johnson carries on this commodification by treating the object with the care and respect usually given to a religious icon or a family heirloom suggests the tension Whitman is working out. What is a "poet of the people" to do when his individual notoriety is already such that fans will archive and pore over every scrap of Whitmaniana they can get their hands on-not to mention scholars over a hundred years hence?

Preservational care notwithstanding, Johnson himself had a fairly ambiguous stance on Whitman, both as a poet and as a cultural figure. In Remembered Yesterdays, Johnson is careful to immediately establish his relationship to Whitman through his relationship with "our common friend, the beloved John Burroughs," who is "one of the saner disciples" (332), mirroring what seems to have also been Scribner's editorial policy in the late 1870's-proximity to Whitman was more acceptable than Whitman himself. While the autobiography counts Whitman among the "Men and Women of Distinction" in the chapter dedicated to Johnson's impressions of these personages, he frequently mixes criticism and approbation: "Whatever else Whitman was, he was not an artist. But he had a power of imagination that gives us the feeling of prairie and sea and sky - and of elemental qualities in human nature" (333). Johnson ultimately arrives at the conclusion that Whitman "was always more or less of a poseur," suggesting that he may have been "in" on the project of the commodification of Whitman's personality - that he knew what he was doing both by refusing to publish the piece and by keeping it around for at least two decades (335).

If Johnson ever studied the back of the document carefully, he would have found a different Whitman there-one who, for a moment, he might have caught out of pose. The Whitman that appears on the reverse of the scrap he used for a new, self-celebratory introduction was the Whitman who would do things other folks did too:

pantaloons ordered by you on Aug 19/79 have been ready for you for some time please advise me what I shall do with them and oblige.

Very Resp.

Geo. A. Castor

While the front triumphantly announces: "Walt Whitman in St. Louis, talk Literature, Politics, and the Prairie States," the back is a plea, sent two months prior to the October interview, from the tailor who had the ill-fortune of having 
the disorganized Walt Whitman as a customer. ${ }^{13}$ In Specimen Days Whitman records himself being in Philadelphia in August of 1879, which means that by the time this scrap of paper found its final use he had carted it with him to St. Louis, Topeka, Denver, and back to St. Louis - the tailor's bad luck was such that the note he sent to Whitman was also the piece of paper nearest at hand when the poet needed to edit some newsprint. Laid up with illness in St. Louis with no other scratch paper close at hand, he made do with what was within reach so that he could make his grand statement on "Literature, Politics, and the Prairie States"-large thoughts, for him, do not necessitate great stationery. One is reminded of his insistence, later in life, that he could find any paper he wanted at any time out of the colossal mess on the floor at Mickle Street. ${ }^{14}$ It is, of course, also possible that even Whitman's careless recycling of a tailor's reminder was intentional: all across his career, Whitman worked hard to cultivate his image of an unappreciated "starving artist" who suffered in the marketplace because of his innovation, and the possibility that he could not afford to pay his tailor could only serve to enhance this element of his persona.

This part of the document could appear insignificant, depending on the eye of the beholder, but it offers a tiny glimpse into another Whitman, one that readers have arguably seen more of today than most did in his lifetime, since the publication of his notes, daybooks, and correspondence: the private Whitman, bard though he may be, going about his domestic affairs like any other resident of Camden, if more forgetfully than some. The manner in which even the back of the document counterpoises the public Whitman of celebrity with the private Whitman of domesticity only becomes more striking as this very juxtaposition plays out across the rest of the "hastily corrected slip."

Whitman's paradoxical relationship with his public image is even more explicitly on display in the corrections Whitman made to the interview itself, beginning with his new hand-written introduction that replaces the opening comments provided originally by the newspaper. Whitman had at least one other clipping of this interview besides the one he sent to Johnson. In the clipping referenced by Floyd Stovall in the notes to his edition of Specimen Days, Whitman cut off the original introduction and simply wrote, "We called on Mr. Whitman yesterday." 15 The newspaper gave a lengthy title to the interview, spanning several vertical lines of print with "Walt Whitman. His Ideas About the Future of American Literature. The Religion and the Politics of a New Nation. Some 
Original Thoughts from a Most Original Thinker."16 The original introductory statement reads:

Walt Whitman, the poet, is visiting his brother at 2316 Pine street, in this city, resting after his trip to Kansas, and recovering from an attack of sickness. Mr. Whitman is a very remarkable looking man. His long, snow-white hair flows down and mingles with his fleecy beard, giving him a venerable expression, which his grave eyes and well-marked features confirm. Whitman impresses one at once as being a sage, and his thoughtful, original speech confirms the idea. A Post-Dispatch reporter called on the author of "Leaves of Grass" this morning, and after a somewhat desultory conversation abruptly asked him: "Do you think we are to have a distinctively American literature?

Note that, while the headline declares the advent of "Original Thoughts from a Most Original Thinker," the introduction penned by the newspaper writer focuses primarily on the poet's singular physical appearance, his hair, beard, eyes, and "well-marked features." Other newspaper interviews Whitman gave on his western excursion follow this trend: the St. Louis Globe-Democrat of September 13, 1879, says, near the beginning: "Although as young as his travelling companion, Mr. Forney, ${ }^{17}$ he is much more venerable and patriarchal in appearance. His quaint garb and primitive collar serve to attract attention to the old gentleman." On the same day, The Missouri Republican began its coverage with: "Walt Whitman is a man well advanced in years and his snow-white hair and long white beard which grows upon a large portion of his face give him a decidedly venerable appearance. He wore a gray travelling suit and his shirt-bosom was left open at the neck, something after the fashion of the Goddess of Liberty as shown on a fifty-cent piece." 18 Whitman was only sixty at the time; nevertheless, newspaper writers were impressed by, and focused on, his physical appearance, which may have been because he cut such a realistic figure, the living embodiment of William Douglas O'Connor's “Good Gray Poet”-playing the part from his dress to his grooming habits. ${ }^{19}$

Whitman's new introduction offers a strikingly different focus: ${ }^{20}$

Walt Whitman in St. Louis, talk,

Literature, Politics, and the Prairie States.

After a journ ^[travel] of some weeks amid the cañons and parks of the Rocky Mountains, and over the Great Plains of Kansas and eastern Colorado, the poet Walt Whitman ^[has] returned to St. Louis, where he is now temporarily residing ${ }^{\wedge}$ resides. He likes ${ }^{\wedge}$ [is much impressed with the whole state of] Missouri, and says the time will come when its natural wealth, situation, and advantages will make it a foremost State in $^{\wedge}[$ member of $]$ the Union. 
A reporter for one of the St. Louis Dailies, the Post Dispatch, called on ${ }^{\wedge}[\mathrm{Mr}$.] Whitman there, one fine forenoon lately, and after a somewhat desultory conversation abruptly asked him:

"Do you think we are to have a distinctively American Literature?"

Note that all references to Whitman's person, his appearance and his family, have been replaced with a terse "the poet Walt Whitman." Even though William Douglas O'Connor had christened him "The Good Gray Poet" more than a decade earlier, Whitman here is much less interested in promoting a public image based on his appearance (which was much the focus of O'Connor's defense, put into the "quaint, sweet tone" of Abraham Lincoln: "Well, he looks like a MAN") and instead focuses on his role as a public intellectual. The handwritten introduction is about Whitman the traveler, off on his longest journey since his early trip to Louisiana, and announcing what he, as America's representative poetic voice, has to say about the Western states. All the reader needs to know about the author personally is that he is "the poet Walt Whitman." Although there are significant passages in Leaves of Grass where Whitman engages a strong poetics of embodiment, here Whitman eschews his body in favor of his thoughts, exchanging his person for his persona.

He could plausibly be erasing his body from his new introduction because it has been giving him so much trouble during his stay in St. Louis. In a letter to Peter Doyle on November 5 he says that he has been "hauled in here in St Louis for repairs," 21 and he also mentions his illness to Anne Gilchrist in a letter from November 10 (“. . . but three weeks ago I was taken down sick \& have come back \& stopt here in St Louis ever since"22), and John Burroughs on November 23 ("I am still here-. . . 'not yet out of my misery")). ${ }^{23}$ There is, however, another possible reading of this remarkably different introduction to the piece: while an individual person has "long, snow-white hair" and a "fleecy beard" (as captured in the original introduction), "the poet Walt Whitman" is more than his appearance. He covers and envisions the "whole state of Missouri," which is itself ultimately not best described as a free-standing, isolated "State" (which Whitman strikes out), but rather a co-dependent "member" of something much larger, namely a collective union. While rhetorically distancing himself from the overpersonalization of the original introductory statement, Whitman simultaneously inflates the status of his individual perspective by prophesying about Missouri's future and giving his impression of its present state, shifting the weight of attention from his body to his voice. The Union is a great collective body and Missouri has a promising future in it because Walt Whitman's singular 
perspective is meant to make it so.

This same paradoxical tension is expressed in that opening question, a query Whitman encounters here not for the last time, which he may ultimately decide is unanswerable later in his career: "Do you think we are to have a distinctively American literature?" 24 The question is hardly surprising, since it was at the forefront of American writers' concerns across the nineteenth century, but there is a meaningful ambivalence at the heart of the question as Whitman approaches it here: is there going to be a distinctive, unique, individual literary voice that will come out of or define a political collective - a relatively young and tenuous one at that? After all, Whitman was traveling West to attend the "Old Settlers' Reunion" on what was only the twenty-fifth anniversary of the settlement of Kansas.

One of Whitman's first deletions suggests his awareness of the keen edge of this ambivalence; after stating that it is necessary for a nation to lay its "materialistic foundations" before anything called a national literature can form, he changes his original text: "This we have founded and are carrying out on a grander seale than ever hitherto, and it seems to me that these great central States from Ohio to Colorado and from Lake Superior down to Tennessee, the prairie States, will be the theater of our great future." Whitman's choosing to unsay a phrase like "on a grander scale than ever hitherto" seems uncharacteristic, idiosyncratic even. Yet recall from above that the question at hand is, "Do you think we are to have a distinctively American literature?"-not a Western literature only. To use the perfect tense ("have founded") and follow it with the imperfect ("are carrying out") implies a division, a separation between the starting place on the coast and the place out West where the work of national infrastructure and trade continues "on a grander scale," and Whitman chooses to do without this division.

It is also worth noting that Whitman was absolutely delighted with the West, that the whole excursion felt like a homecoming to him, in spite of his illness that kept him laid up in St. Louis for longer than he expected to be on his return trip. "I have found the law of my own poems" he wrote while riding the train through the Rocky Mountains, ${ }^{25}$ and in one interview Whitman defines himself as "in sympathy and preference Western-better fitted for the Mississippi Valley." 26 In the section of Burroughs's "Nature and the Poets," which Whitman had written about himself around this time, he also makes sure to say, "Whitman is less local than the New England poets, and faces more to the West." 27 And yet, in his revision of the interview, he finds himself reluctant to sever the American West too cleanly from his home in the East, 
toning down his celebratory language to describe more moderately the role that a single part of the country will have in the making of its collective voice. As he goes on to say (and unsay): "Ohio, Illinois, Indiana, Missouri, Kansas and Colorado seem to me to be the seat and-field of these very ideas. They seem to be earrying them out." The Mid-Western states may still be the "field" of the foundations of possibility for a national American literature, but they are not the exclusive "seat" of these foundations, and Whitman no longer finds it necessary to point to them as carrying it out in any unique way. Whitman's first significant revisions following the introduction thus suggest a special concern with the problem of national identity - in order to be able to say what an "American national literature" is, he would have to say what America is, but he finds it very difficult to describe America without chopping it up into regional pieces, so he opts for a moderation in tone to help soften, at least for the moment, his triumphant opinion on the progress of American westward expansion, erring on the side of democratic unity. In the spirit of late-career Whitman, nationalistic triumphalism will feature much more prominently later on.

A few more mostly cosmetic deletions follow. The next more meaningful change, for the purposes of my argument here, is an insertion: "^[Hitherto,] Although we have elegant and finished writers, none of them express America or her spirit on any respect whatsoever." The insertion caret is placed before the word "Although," and "Hitherto" is written in the margin on the heavy stock to which the clipping is glued. Had the word been printed in the original it may have spared Johnson the concern out of which he wrote to Whitman in the first place. The insertion suggests that, when publicly responding to a query about the possibility of a distinctly national American literature, Whitman wants it to be known that there have "hitherto" been no writers who "express America's spirit"- not yet, but one day. It may be that he is unable to articulate for Johnson in whom specifically these hopes should be placed because he is engaging in the same process of cultivation that he tackles in Leaves of Grass - he is hoping that, by invoking the next generation of American poets, he may be able to speak them into existence. "Hitherto" indicates the possibility of something coming later, coming after, which is not yet here but may one day be, if the seeds are scattered into the right soil. In his letter back to Johnson that accompanied this piece, Whitman says he is invested in "a certain leaven \& spirit," not a new movement of disparate, individual genius - but his public self is hopelessly, individually charismatic. Whitman wants to inaugurate a bold, fresh, new democratic poetics, but since the crux of the experiment is the convergence of the individual and the mass, he cannot be satisfied with mere disciples or imitators. 
He wants to put "a whole living man in the expression of a poem" (as he will say later in the interview), but that living man is supposed to also reveal the secret of democratic unity, by containing multitudes. It may therefore be one of Whitman's more profound, if subconscious, revelations, that the resolution of this quandary is always deferred: and yet, in his private revision of his public thoughts, Whitman inserts the "hitherto" of a hope that his promise of a new generation might materialize as he calls it into being.

Next, the interviewer asks Whitman, "What will be the character of the American literature when it does form?" A long deletion follows: "Đo you know that $I$ have thought of that vaguely often, but have never before been asked the question. It will be something entirely new, entirely different. As we are a new nation with almost a new geography, and a new spirit, the expression of them will have to be new." Whether he really has never been asked the question in the past, or if simply does not want to say that he has considered the issue only "vaguely," Whitman's editing pen decides that it does not behoove him to appear ambivalent in his response. He says that Americans will write in "the same old font that Homer and Shakspeare used, but our use will be new," deleting even the mention of the "old." Whatever American literature may be, insofar as it will draw upon pre-existing ideas and forms, it will draw upon them in an unprecedented way. ${ }^{28}$

In a similar vein, Whitman's next insertion is concerned with moving beyond what is "foreign" in the modern literary landscape, to get to the kernel of what he believes to be really "American" in American poetry. The interview says, with the added word marked by a caret, "Modern poetry and art run to $\mathrm{a}^{\wedge}$ [constipated] sweetness and refinement which are really foreign to us; they are not ours." The invocation of "sweetness and refinement," reminiscent of Matthew Arnold's "sweetness and light," seems to indicate the general tenor of the "Fireside Poets" like Whittier, Bryant, and Longfellow. Whitman would also resort to the metaphor of constipation about a decade later when describing Puritanism and its relation to "a great imaginative literatus for America."29 Whitman is quick to criticize his contemporaries, in this interview and elsewhere, for trying to import what he saw as fundamentally European ways of writing into American letters, and it is clear from his insertion that he felt such influences were causing some kind of unique American literary spirit to become blocked or stopped up in an unproductive way.

Whitman's concern here about the intrusion of the foreign signals his embrace of American exceptionalism-he believed that there were not and could not be any greater countries in the world, and later in this interview he 
says that the reason America does not own the whole world is that the whole world isn't "fit" to be owned by it: "We could take the whole world in if it was fit for it, which it is not. There is no danger in enlargement. We can take in all the country from the isthmus to the North pole." Whitman's failures are as loud as his successes, and rarely secret or subtle. Yet, considering the apparent paradox of the relationship between the individual and the masses that he grapples with here, America suggests itself to Whitman as a solution to the problem, heavyhanded and troubling as Whitman's boundless enthusiasm makes it appear. As Whitman saw it, America was unique because of its masses-the ideal synthesis of the dialectical tension between individual and mass. America's particular potential was in its general "leaven \& spirit," as a republic constituted by the mass of its people. Whitman believed that such a synthesis was possible, and that a poet could bring it about, if that poet became himself the microcosm of the democratic nation he envisions - and if he could get his public opinion about the matter printed just right. Whitman was, as this document emphasizes, convinced that utopian democracy was at his beck and call.

This idea is borne out further in Whitman's next significant insertions a few lines down the page: "My idea of one great feature of American poetry is the expression of comradeship. That is a main point with me. Then breadth, moderness ${ }^{\wedge}[$,$] and consistency with science { }^{\wedge}$ [and our own idiosyncrasies, east and west, north and south]." It is not enough for Whitman that American literature be generally broad, modern, or consistent with science ${ }^{30}$ - it should bear all these things while maintaining the unique terroir of the various parts of the country. He wants a general sort of breadth that also preserves particular uniqueness, in a manner similar to his own massive poetic geographical catalogues, like those in "Salut au Monde!" or "Starting from Paumanok." Hence, when he comes to the statement that prompted Johnson's letter, the changes that at first appeared idiosyncratic now come into focus:

The best promise in America of those things is in a certain range of young men that are coming on the stage, that are yet voiceless. They are appearing ${ }^{\wedge}[$ both] in the Eastern cities and in the West. They have not yet begun to speak because the magazines and publishing houses are in the hands of the fossits. There is a great underlying strata of young men and women who eannot speak beeatse the magazines are in the hands of old fogies like Holland or fops like Howells. They ${ }^{\wedge}$ [Those young souls] are like water dammed up. They will burst forth some day.

Whitman handles the section Johnson had inquired about by deleting much of it, apparently more concerned about the periodical market than about book 
publishers, and no longer concerned about "fossils." He carelessly deletes women from America's literary future for simple editorial convenience-the original had "men and women," but Whitman crosses out that entire line, leaving only the "certain range of young men" at the beginning. On the other hand, a generic "they" is insufficient to describe the group of "young souls" Whitman has in mind. It may appear unusual that Whitman retains the derogatory reference to Josiah Holland, but Whitman and Holland's mutual animosity was hardly a secret. In 1875, Whitman sent two poems to Holland, one of which was "Eidólons." Whitman later recalled to Horace Traubel that the letter he received in return was "the most offensive and abusive letter I ever received." 31 Whitman claimed to have burned it, but a sense of what it may have contained can be surmised from a different letter from Holland that Johnson reproduces, in which he says, "A good brain with all its energies wasted on a style so irredeemably vicious that no man can ever imitate it without disgrace - that is Walt Whitman to me"(Remembered Yesterdays, 338). In May of 1876, Holland published the scathing editorial "Is It Poetry" in Scribners, staunchly proclaiming that Whitman's work "has no right to be called poetry; that it is too involved and spasmodic and strained to be respectable prose, and that there is no place for it, either in the heaven above, or in the earth beneath, or in the waters under the earth." 32 In 1878, Holland demonstrated laughable failure as a literary oracle, writing in an editorial called "Our Garnered Names" that "when the genuine geniuses of this period shall be appreciated at their full value . . . their countrymen will have ceased discussing Poe and Thoreau and Walt Whitman." 33 It would appear that the only kind words about Whitman that Holland ever published were from the mouth of John Burroughs, who published "Is It Going to Rain?" in Scribner's in 1878, one year before publishing it in Locusts and Wild Honey, and his more famous essay "Nature and the Poets" in 1879, two years before including it with the essays in Pepacton. Burroughs, of course, speaks glowingly of Whitman in both pieces, but also seems to have made himself respectable enough in the eyes of the Scribner's editors that they are willing to concede: "Mr. Burroughs is so charming a companion that one is quite willing to have a difference of opinion with him." 34 Josiah Holland's Scribner's was apparently only ready to accept a Whitman mediated through the veil of Burroughs' relative presentability, which makes it both unusual that Johnson reached out to Whitman at all and unsurprising that Whitman felt no qualms about taking "old fogie Holland" to task.

On another level, Whitman is trying to indicate that Johnson's query itself shows how deeply he has missed the point. He is not saying that there is individual literary genius lying undiscovered all across America, and that if the 
traditional mechanisms of literary authority would but subsume these voices under their umbrella, an American poetics would finally "burst forth." Rather, a truly democratic American poetics would be one that broke completely with the traditional model of literary publication based on finding the next great individual talent, allowing for the possibility of a speaking mass, a voice of "comradeship," as Whitman put it before. Once again, the promise is deferred-America may have a literary future, but for now there are constipating forces damming them up, forces in the literary establishment preventing the "bursting forth" of the "young souls." These forces must be subverted entirely before breadth and uniqueness can coexist, although Whitman avoids confronting the contradiction which cannot possibly be lost on him here, that the experimental nature of his own attempts to articulate this subversion is what makes him stand out as an individual opposed to his contemporaries.

This is, however, his exact concern about Bret Harte, one of the early novelists to write about the American West. In this interview, Whitman excoriates Harte for choosing the wrong sort of individual characters and making them stand for the whole of the West: "^[But] What a miserable business it is to take out of this great outgrowth of Western character, which is something more heroic than ever the old poets ${ }^{\wedge}$ [and historians] wrote about, tove taken out only a few ruffians and delirium tremens ${ }^{\wedge}$ [ital] specimens, and made them representatives of California personality." Instead, the essence of the West would have better been expressed by, in a phrase Whitman adds in the margin, "the loftiest native types." Since Whitman's first-person voice in his poetry tends to represent itself as a part speaking for, and encompassing, the whole, it would appear that a "loftier native type" would look more like Walt Whitman himself, and less like Harte's actual characters who, as Whitman puts it, "have taken Dickens' treatment of the slums of London and transferred it to California." As David Haven Blake notes about Democratic Vistas, "When Whitman envisions a 'divine literatus' who might make the nation whole, he imagines a figure that strikingly resembles an earlier version of himself" (207).

Indeed, after inserting a question for the interviewer that allows him to make some brief laudatory remarks about Tennyson, and irritably suggesting that "the whole tendency of poetry has been toward ${ }^{\wedge}$ [a twiddling sort of] refinement," Whitman considers the exact problem Blake brings to light:

Something more vigorous, al fresco, was needed, and $\mathrm{t}^{\wedge}[\mathrm{T}]$ hen more than all I determined from the beginning to put a whole living man in the expression of a poem, without wincing. I thought the time had come to do so, and I thought America was the place to do it. Curious as it may appear, it had never yet been done. An entire human being physically, emotionally, 
and in his moral and spiritual nature-^[,] And also to express what seems to be to have been left unexpressed, our own country and our own times.

Perhaps Whitman does not want it to appear "curious" that no one has attempted to "put a whole living man in the expression of a poem," as he puts it. But this is the problem: no one has attempted it because no one else is Walt Whitman. His vision for the literary future is largely drawn from his own poetic self of the pastthe renegade, self-publishing "rough" from the famous image that accompanied the 1855 Leaves of Grass. But Walt Whitman is not a single, unified self-he is a multitude of selves, trying to present a vision of a collective poetics that seamlessly unites the human being, already fragmented and disparate, into a whole, and at the same time to express "our own country" through that expression of composite individuality: not what has been left unexpressed about "our country" or in "our country," but the national collective itself. This is why he sends these hasty corrections to Johnson instead of a carefully curated list of budding new American literary talent: he knows that he is doing something unique, but if the unprecedented nature of the work relies on the specific individuality of the author, it cannot be repeated any more than a whole individual person's life can be relived. The phrase "it had never been done" becomes troublesome and is crossed out, not because Whitman secretly believes that a project like his has been attempted before, but because too heavy a focus on the unprecedented nature of his project would suggest that the reason these underlying strata have yet to speak is not because they are crushed by the literary establishment, but because they are not Walt Whitman, a reversion to the language of individuality which would undermine his entire argument thus far.

As the interview turns towards politics at its close, Whitman looks to the nation to solve his conundrum of the individual and the masses, because it is finally in what he calls the "greatness" of the nation that the marriage of individual expression and mass collectivity is finally consummated, wrapped uncomfortably in rhetorics of expansionist imperialism that Whitman first employed in his early days as a writer and more fully embraced in the later decades of his career. After a very brief and general statement on religion, to which he makes no noteworthy changes, Whitman first fixes a mistake in the original text, and then he institutes a series of revealing changes. First, the original text of the interview reads, "I think the theory and practice of American government, without its 
National and State governments, are stable. It seems to be established without danger, without end." In the slip he sent to Johnson, the first "without" is shortened to "with," so the clause carries the opposite meaning; it now says, with my emphasis added, "with its National and State governments." It seems most probable that this is a case in which the printer or the journalist actually did make a mistake and print his words in a "dislocated \& awry manner," since the practice of American government minus both the national and the state political bodies would not leave much to comment upon.

Whitman continues to celebrate the practice of American government, adding the phrase "and Cuba" to the interviewer's question: "And how about ^[Cuba and] Canada?" As Louis A. Pérez, Jr., writes, "The nineteenth-century premise of American nationhood was fully imbued with the presumption of possession of Cuba, anticipated with the supposition of certainty and awaited with the expectation of fulfillment." ${ }^{35}$ While the 1898 invasion of Cuba was still years away, the potential annexation of Cuba was debated widely across the nineteenth century, and Whitman himself weighed in on the debate in the January 12, 1858, Brooklyn Daily Times: "Judging from analogy and precedent, as well as from the geographical position of Cuba, there can be little doubt that, like Texas and other States, it will gradually be absorbed into the Union. . . . It is impossible to say what the future will bring forth, but 'manifest destiny' certainly points to the speedy annexation of Cuba by the United States." 36 His insertion of Cuba into the interviewer's question is therefore not a simple statement of geographical reality (that Cuba belongs in the same "group," for the project of American empire, as Canada and Mexico), but a signpost that Whitman is weighing in on an issue integral to the political concerns of the day, one that had been on his mind for at least two decades.

His 1858 embrace of "manifest destiny" is also highlighted in his response to the newly articulated question, although not in terms as explicit as those of his earlier journalism: "I think Canada and Cuba and Mexico will gravitate to us. We could take the whole world in if it was fit for it, which it is not." Furthermore, where the original text of the interview prints, "Our American greatness and vitality are in the bulk of our people," he crosses out "greatness" and replaces it with "dominion," but then he follows it up with, "not in $\mathrm{a}^{\wedge}[\mathrm{]}$ gentry ${ }^{37}$ like in the old world." This is yet another of his paradoxical dilemmas: Whitman haughtily says that the world is "not fit for" America, but this is at least in part because that world is too entrenched in hierarchical systems of aristocracy. Whitman's exaggerated jingoism therefore unwittingly highlights the imperialism latent in the project of American liberal democracy while simul- 
taneously calling for the abolishment of class hierarchy. True to form, given the choice between two apparently irreconcilable positions, Walt Whitman chooses both. While the individual nation in its relationship to the mass of the continent is at issue here, this move is fundamentally indicative of Whitman's attitude towards the problem of the individual and the collective, whether that be in poetry, philosophy, or politics.

At the end of the interview, Whitman does make one definitive move in the direction of the democratic "bulk" he has been extolling. To understand the significance of this moment, it will be important to remember that 1879 was the first year that Whitman publicly gave his lecture on the "Death of Lincoln." Throughout the year he had been grooming the press to prepare the public for his reinvention, not simply as a poet, but as a public orator. On April 15, 1879, he wrote a piece for the New York Daily Tribune entitled "The Poet on the Platform," subtitled "Walt Whitman as a Lecturer," and starting with, "The poet Walt Whitman made his beginning as a lecturer last night, at Steck Hall, in Fourteenth-st." ${ }^{38}$ Later in the year, the November 15 Washington Evening Star includes a brief segment by Whitman entitled "A Poet's Western Visit," which briefly describes his trip out West but also carefully states that "He [Whitman] is understood as desiring engagements to lecture and read his poems the coming winter." ${ }^{39}$ The Lincoln lecture, often coupled with a reading of "O Captain! $\mathrm{My}$ Captain!” would become a staple element of Whitman's travelling repertoire at this point in his career. It is with this context in mind that the significance of his next change to the interview comes into focus. The original said, "Our leading men are not of much account and never have been, but the average of the people is immense, beyond all history. Lincoln seems to me to be our greatest specimen personality. Sometimes I think that in all departments, literature and art included that will be the way our greatness will exhibit itself. We will not have great individuals or great leaders, but a great bulk, unprecedentedly great." His revised version reads: "Lineoln seems to me to be our greatest specimen person= ality. Sometimes I think that in all departments, literature and art included that will be the way our greatness`[true American soul] will exhibit itself. We will not have great individuals or great leaders, but a great bulk, unprecedentedly great." Whitman shows himself in this moment to be so dedicated to the idea of the collective, to the bulk and the mass, that he no longer sees any room for "specimen personalities," even that of Lincoln, at this precise moment when Whitman is actively working to brand himself as a public lecturer about Lincoln. At the interview's close there is, at last, a definitive statement of the subsumption of the individual into the democratic bulk that Whitman is so fond 
of extolling - but it is a statement founded upon an absence that is only apparent when considering the document in this specific form, since the excision would not be visible in any print form.

On the one hand, Whitman dials up his nationalistic rhetoric in order to express the colonial imperialism of his context in ways that ring uncomfortably false in the mouth of a poet who is capable, at times, of genuinely liberatory poetic intentions. For sure, his invocation of manifest destiny all the way back in 1858 indicates that various forms of imperialism wove their way in and out of his personal and poetic ideology all throughout his life. On the other hand, he shows himself so dedicated to an anti-aristocratic poetics of the mass that he goes so far as to delete Lincoln from his conclusion, even though singing Lincoln's praises on the lecture circuit would become his bread and butter in the years to come. His subtly anarchic "no kings, no heroes" attitude-expressed here and in a later conversation with Horace Traubel- "I'm honest when I say, damn My Captain and all the My Captains in my book!" 40 - is stated in the same breath as "American greatness and dominion." His conclusion, that the greatness of the nation is its subsumption of class hierarchy and individual greatness into a sphere of exceptionally horizontal collectivity, is his answer to Johnson. If an American literature is going to form as such, it will be a great collective experiment that relies on its horizontal nature for its potency. Whitman's romantic ebullience leads him to overstate this case with indulgent expansionist rhetoric, as he tries to square the circle of all his selves, which sometimes for worse and sometimes for better, he cannot help but sing.

With this glimpse into Whitman's edits in his "hastily corrected slip," it is possible to see the complex interplay between individual and mass that Whitman needed to navigate as his own popularity grew. At the same time, he had to grapple with the irony that his individual notoriety was in a sense all he had to show for his attempt to inaugurate a revolution in poetic form. He had admirers and imitators, but his radical redefinition of poetic form would spend decades after his death going through the permutations of modernism before producing a Carl Sandburg or an Allen Ginsberg. The very existence of this document demonstrates that Whitman knows Johnson has called his bluff, but it also shows the way he is trying to stack the deck in his favor by calling "the best promise in America" into being. For example, Johnson himself expresses surprise 
at Whitman's having anything positive to say about Tennyson, "the chief of the mid-Victorians." Johnson considers Whitman's statement that Tennyson is "the leading man in modern poetry" evidence that "[Whitman] did not hold consistently to his theory and practice of verse." "But Whitman explicitly says in the interview that, while Tennyson captures "the heart-sickness of modern times," he is personally "ambitious to do something entirely different from that ... something more vigorous, al fresco." America for Whitman cannot be articulated through the modern ennui of a particular moment, but ought instead to be expressed in something bigger than any one historical moment: "a whole living man in the expression of a poem, without wincing." Whitman does not see his poetic American democracy as a product of modernity, but as an answer to the problems that modernity brings to the fore as a distinct but magnetically attractive force. Perhaps it was this idealistic desire to drench modernity in timelessness that made it so difficult for Whitman to call his democratic republic of bards into being.

Many concessions to the split between form and content have been made here in order to make the piece as legible as possible to a community of scholars interested both in what Whitman has to say and the material means by which he says it. In truth, the words Whitman says, unsays, and re-says in his "hastily corrected slip" cannot be separated cleanly from the object on which they are inscribed. In a year that he had dedicated to travel and to carefully cultivating his image as a public intellectual in the periodical market, Walt Whitman the individual worked hard to control the narrative by which he would be received en masse. While there is of course an element of egotism to such a project, it is not self-aggrandizement, pure and simple. Whitman believed that the edifice of self he constructed at this time would be the foundation of a new explosion of literary democracy, just as he believed that the laying of "materialistic foundations" would be the "seat and field" of the Western states he had experienced for the first time. In his reply to Johnson, he subtly changes the original so that it is no longer an interview about Walt Whitman, but an interview given by Walt Whitman, which becomes in turn an attempt to reconcile his own competing public and private selves into a coherent whole, from which he can speak multitudes. With his edits to this document, Whitman pieces together the always-deferred possibility of a democratic literary voice that both speaks the whole subjectivity of an individual and celebrates the levelling power of a mass collective on the national scale. Whitman's final iteration of his words on the matter was framed and hung on the wall without ever reaching publication and now rests quietly in the vault of a rare books library, but this artifact offers 
a hasty snapshot of the springs and cogwheels of the project of self-making underlying the democratic impulses of Whitmanian poetics. As he tinkers with his identity here, this collage offers some hints as to how he intended to get the whole unwieldy apparatus to travel ahead of him, on its own, into the democratic literary future of his imagination - an imagination by turns prodigious and fallible, fractured and singular.

\title{
Indiana University
}

\begin{abstract}
Notes
1 The author is gratefully indebted to the staff at the Lilly Library for their invaluable assistance, in particular to Zach Downey for his careful digitization of the piece, Jim Canary for his assistance in re-assembling the piece together with the frame, and to the public services librarians Sarah Mitchell, Rebecca Baumann, Maureen Maryanski, and Isabel Planton, all of whom have been of incalculable assistance over the course of this project.
\end{abstract}

2 Scans of both sides of the document can be seen on the Lilly Library's "Whitman in St. Louis" page, from the digital exhibition "Whitman at the Lilly" (indiana.edu/ liblilly/digital/exhibitions/exhibits/show/whitmanlilly/mask/stlouis). Dr. Christoph Irmscher, to whom I am also deeply indebted for his generosity regarding essentially every aspect of this project, provides critical commentary and a partial transcription in the online exhibit.

3 Consider, for example, his statement to Horace Traubel: "Having been a printer myself, I have what may be called an anticipatory eye-know pretty well as I write how a thing will turn up in the type-appear-take form"; With Walt Whitman in Camden 5:390 (hereafter WWC, available on the Walt Whitman Archive, whitmanarchive.org).

4 Robert Underwood Johnson, Remembered Yesterdays (Boston: Little, Brown, and Company, 1923), 335.

5 Whitman, "To Robert Underwood Johnson," in Edwin Haviland Miller, ed., Walt Whitman: The Correspondence, Volume 3: 1876-1885 (New York: New York University Press, 1964), 167. Available on the Walt Whitman Archive (uva.00388).

6 I am paraphrasing the famous line from Whitman's "So Long!," added to the third edition Leaves of Grass in 1860, available on the Walt Whitman Archive.

$7 \quad$ According to one source, Holland's Titcomb's Letters to Young People, Single and Married sold 62,000 copies in the United States from 1858 to 1881 . Holland's 1868 poem Kathrina is also stated to have "outsold all other American poems except Longfellow's Hiawatha" (185). See H. Clay Williams, Biographical Encyclopaedia of Massachussetts of the Nineteenth Century, Volume 2 (Boston: 
Metropolitan Publishing and Engraving Company, 1883).

$8 \quad$ See Johnson 337.

9 For the text of the entire "interview," see Rollo G. Silver, "Walt Whitman Interviews Himself," American Literature 10 (March 1938), 84-87.

10 The essay by Burroughs was published in the December 19, 1879, edition of Scribner's Monthly, the same publication that Robert Underwood Johnson worked for at the time. It is also published in Burroughs' collection of essays Pepacton, and while the essay contains some interesting thoughts from Burroughs it is really worth reading to see the sudden, obvious, unattributed change in diction from Burroughs to Whitman and back. Even better, in a letter sent November 23, 1879, Whitman tells Burroughs: "What you say of me in Nature $\mathcal{F}$ the Poets thoroughly delights, satisfies \& prides me"-Whitman congratulates Burroughs for simply publishing the words he wrote for himself (See Miller 170-171; Walt Whitman Archive, ucb.00056). Since the St. Louis interview in question here has always been attributed anonymously, it would be truly delicious if Whitman had also written it for himself in the first place, but based on the archival record as it stands now, such speculation is only suitable for a footnote.

11 Here I am quoting the lines that appeared in the first poem of the 1855 Leaves of Grass (available on the Walt Whitman Archive), which were incorporated into the poem Whitman called "Song of Myself" in later editions: "Do I contradict myself? / Very well then . . . . I contradict myself; / I am large ... . I contain multitudes.”

12 David Haven Blake, Walt Whitman and the Culture of American Celebrity (New Haven: Yale University Press, 2006), 197.

13 Thanks to Emer Vaughn for her work identifying the tailor.

14 He expressed deep consternation with his Mickle Street housekeeper, Mrs. Davis, when after a week-long excursion elsewhere he returned to find the house tidied up: "He said that he had left everything exactly as he wished it to remain; where he could find it; now the very things he needed most were gone; in fact he could find nothing he wanted, and in the future he forbade anyone to meddle with his private property; he desired and expected to find-at all times and upon all occasions-his personal matters unmolested, undisturbed, left entirely alone." See Elizabeth Leavitt Keller, Walt Whitman in Mickle Street (New York: Mitchell Kennerley, 1921), 32.

15 See Stovall 224, footnotes to lines 1-3 of Whitman's “An Interviewer's Item” in Specimen Days. It appears that, even in the version of the interview that he kept for his own private use, Whitman was so displeased with the original introduction that he cut it off.

16 The interview has been digitized on the Walt Whitman Archive under "Commentary: Interviews and Reminiscences." Walt Whitman Archive ID: med.00531.

17 Whitman was traveling with Colonel John W. Forney, a Philadelphia journalist who published the weekly magazine Progress. Forney served twice as the clerk of the House of Representatives and, 
for one seven-year stint, as the secretary of the United States Senate during the Civil War. The full interview, "Walt Whitman, the Poet," is available on the Walt Whitman Archive (ID: med.00528).

18 "Two Visitors," available on the Walt Whitman Archive, med.00674.

19 O'Connor's essay The Good Gray Poet: A Vindication was originally published as a pamphlet (New York: Bunce and Huntington, 1866), later reprinted in Richard Maurice Bucke's biography Walt Whitman (Philadelphia: David McKay, 1883), and is available from the Walt Whitman Archive (anc.00170).

20 Note that Whitman also crossed out and changed a number of phrases even in his own introduction for the piece, and my transcription maintains these changes with strikethrough text.

21 See Walt Whitman, The Correspondence, vol. 3, ed. Edwin Haviland Miller (New York: New York University Press, 1964), 168. Walt Whitman Archive, loc.01628.

22 Correspondence 3:169. Walt Whitman Archive, loc.02140.

23 Correspondence 3:170. Walt Whitman Archive, ucb.00056.

24 Whitman, "American National Literature: Is there any such thing-or can there ever be?" Walt Whitman: Prose Works 1892, Volume II, Collect and Other Prose, ed. Floyd Stovall (New York: New York University Press, 1964), 668: "The whole matter has gone on, and exists to-day, probably as it should have been, and should be; as, for the present, it must be. To all which we conclude, and repeat the terrible query: American National Literature-is there distinctively any such thing, or can there ever be?" The essay originally appeared in the North American Review (March 1891) and subsequently in Good-bye My Fancy.

25 See p. 210 of the Stovall edition of Specimen Days, under the heading "An Egotistical 'Find."”

26 "Walt Whitman, the Poet," (Walt Whitman Archive, med.00528).

27 Burroughs, Pepacton 108. The quote here comes from the edition digitized by Google Books, which is volume five of the "Riverside Edition" of The Writings of Fohn Burroughs, published by Houghton Mifflin in 1895. While it is more traditional to cite the physical edition of a widely available printed text, it just so happens that the edition digitized by Google from Harvard was the copy owned by Sarah Orne Jewett, donated to Harvard from the Jewett homestead, and I believe this edition suits the archival nature of this project. Whitman's personal copy of Pepacton, inscribed to him from John Burroughs, is housed at the University of Iowa Libraries Special Collections.

28 Homer and Shakespeare are among Whitman's regularly invoked favorites, as in the piece he wrote about himself for Burroughs where he claims that "[John] Addington Symonds . . . finds him [Whitman] more thoroughly Greek than any other man of modern times" (109).

Whitman, "American National Literature ...” 666. 
30 This concept of scientific consistency is important for Whitman and especially on his mind at this time-in the Burroughs piece he elaborates: "In entire consistence with botany, geology, science, or what not, he [Whitman] endues his very seas and woods with passion, more than the old hamadryads or tritons. His fields, his rocks, his trees, are not dead material, but living companions" (109).

31 Horace Traubel, With Walt Whitman in Camden (Philadelphia: University of Pennsylvania Press, 1953, hereafter $W W C$ ), 4:326. This text is available on the Walt Whitman Archive, and links to other relevant sections of Traubel's text are provided in the Archive's notes on Whitman's original letter to Holland (Walt Whitman Archive, nyp.00270).

32 Josiah G. Holland, “Is It Poetry,” in Scribner's Monthly, 12 (May 1876), 123. Holland's personal authorship of this piece is verified by its republication in his 1882 Book of Briefs, which lists him as the author on the frontispiece.

33 Josiah G. Holland, “Our Garnered Names,” in Scribner's Monthly, 16 (October 1878), 895.

34 “John Burroughs's 'Birds and Poets.” In Scribner's Monthly, 14 (July 1877), 407.

35 Louis A. Pérez, Jr., Cuba in the American Imagination: Metaphor and the Imperial Ethos (Chapel Hill: University of North Carolina Press, 2008) 25.

36 "The Gem of the Antilles" in Emory Holloway and Vernollian Schwarz, eds., I Sit and Look Out: Editorials from the Brooklyn Daily Times by Walt Whitman (New York: Columbia University Press, 1932), 157.

37 Whitman is here fixing a typesetting error on the part of the newspaper's printer, which had "agentry" in the original.

38 This paper has been archived and digitized by the Library of Congress and is viewable at chroniclingamerica.loc.gov/lccn/sn83030214/1879-04-15/ed-1/seq-2/.

39 Available on the Walt Whitman Archive, med.00532.

$40 \quad W W C 2: 304$

41 Johnson 335. 